\title{
Bermuda Grass Pollen IgA Measurement
}

National Cancer Institute

\section{Source}

National Cancer Institute. Bermuda Grass Pollen IgA Measurement. NCI Thesaurus. Code C130069.

A measurement of the Bermuda grass (Cynodon dactylon) pollen IgA in a biological specimen. 